\title{
Diversity of mung bean insect pests and their natural enemies in farmers' fields in East Java, Indonesia
}

\author{
SRI WAHYUNI INDIATI", BEJO, M. RAHAYU \\ Indonesian Legumes and Tuber Crops Research Institute. Jl. Raya Kendalpayak Km 8, PO Box 66, Malang 65101, East Java, Indonesia. \\ Tel.: +62-341-801468, Fax.: +62-341-801468, ”email: swindiati@yahoo.com
}

Manuscript received: 2 November 2016. Revision accepted: 9 August 2017.

\begin{abstract}
Indiati SW, Bejo, Rahayu M. 2017. Diversity of mung bean insect pests and their natural enemies in farmers' fields in East Java, Indonesia. Biodiversitas 18: 1300-1307. A survey was conducted from June to September in 2016 in mung bean fields in East Java. The objectives of this survey were to identify the mung bean pests that were present, and to identify potential natural enemies of these pests at each location. Insect pests recorded in low numbers in all fields surveyed were bean fly (Ophiomyia phaseoli), thrips and grasshoppers. Pod sucking bugs (Nezara viridula, Piezodorus hybneri, and Riptortus linearis) were found in all fields in all months. The population densities of pod sucking bugs were relatively high, and represent a major threat to mung beans in Indonesia.White flies (Bemicia tabaci) and leafhoppers (Empoasca spp.) were found in low numbers in all fields surveyed during the August-September period. Several new pests of mung bean were recorded in this survey: the leaf beetle (Megacopta cribraria) was recorded in fields in the villages of Pungkurlawas, Brondong, Lamongan; and pod boring weevils (Apion clavipes, Curculionoidae) were found in high numbers in Madiun and Nganjuk, resulting in significant damage to mung bean pods. Natural enemies of insect pests recorded during the survey were spiders, dragonflies, Hymenoptera (Braconidae and Trichogrammatidae), Diptera (Tachinidae and Syrphidae), and Coleoptera (Coccinellidae and Paederus fuscipes). Natural enemies - spider and Coccinella predators - were present in low numbers in all fields surveyed, although Coccinella predators were not present in Lamongan.
\end{abstract}

Keywords: East Java, insect pests, mung bean, natural enemies

\section{INTRODUCTION}

In Indonesia, mung bean (Vigna radiata $\mathrm{L}$.) is the third largest Leguminosae crop after soybean and peanuts. This plant is cultivated by farmers because the price is relatively stable and more competitive than soybean (Basuki et al. 2011). In 2011, the production of mung bean in Indonesia reached 341,342 tons of dry grains with an average of 1.148 t/ha (Directorate General of Food Crops 2012). Mung bean production still does not meet the increasing demand of the community. An average of 322,098 tons of mung bean are needed, while an average of only 313,229 tons of mung bean are produced each year, so the government has had to import about 29,443 t/year (BPS 2012).

Mung bean can be grown in a wide range of soil types, and can be grown throughout the year in Indonesia. Planting of mung bean in paddy fields is done in the dry season after the rice harvest, with the cropping pattern ricerice-mung bean. In dryland fields, mung beans are planted at the end of the rainy season after upland rice or maize (Radjit and Prasetyawati 2012). Mung beans can be planted in dryland areas because it has a short life (matures quickly), is resistant to drought, and is less susceptible to pests than soybean (Radjit and Prasetyawati 2012). Various methods have been used to increase the production of mung beans, including system intensification, extensification, and land rehabilitation, as well as by reducing attack by pests and diseases (Radjit and Prasetyawati 2012).

Insect pests on mung bean can be classified into: (i) stem feeders, (ii) foliage feeders, and (iii) pod feeders
(Tengkano 1986). At the seedling stage, agromyzid beanflies Ophiomyia phaseoli (Tryon), are the most common pest. Ophiomyia phaseoli larvae feed on the cortex within the stem and pupate in the cortex. Sometimes pupae can be seen under the membranous epidermis. The foliage feeders, especially defoliators that belong to Lepidoptera and Coleoptera, include: the leaf-folder, Lamprosema indicata (F.); caterpillars of Spodoptera litura (F.); hornworms, Agrius convolvuli (L.); ladybirds, Henosepilachna spp; leaf beetles of the Chrysomelidae; and the grasshoppers, Attractomorpha crenulata crenulata (F.). The sap-feeding insects include Aphis craccivora Koch; the jassid, Empoasca kerri Pruthi; white flies, Bemisia tabaci Gennadius; thrips from the genus Megalurothrips Bagnall; the pod sucking bugs, Riptortus spp., Nezara viridula (L.), and Plautia fimbriata (F.); and pod bugs, Clavigralla spp. These pests cause significant damage to mung bean foliage and pods. Beetle of the genus Mylabris (F.) cause serious damage to the flowers, especially to the second and third flush of flowers during August-September, in most mung bean cultivation areas in Muneng, Prolinggo, East Java. The lepidopteran pod borer, Maruca vitrata (F.), has also been reported as a major pest of mung bean.

In Indonesia, some of the major pests that are considered harmful to mung bean crop are thrips, armyworm (Spodoptera litura), pod borer (M. virata), and pod sucking bugs (Riptortus linearis (F.), Nezara viridula (L.) and Piezodorus hybneri (Gmelin) (Baliadi 2007; Indiati 2015; Marwoto and Harsono 2008). 
According to Kogan and Turnipseed (1987), pest status may be altered by one or a combination of several factors: changes in cultivation, changes in the efficiency of natural enemies (pathogens, parasitoids, and predators), changes in application frequency of insecticides, changes in the value of commodities that will change the value of the level of economic damage, and changes in planted varieties. Recording of insects associated with mung bean plants in some agricultural ecosystems in Indonesia is indispensable. Information on the composition of pest species and their natural enemies at various mung bean sites is vital as a basis for determining the policy of integrated pest management. In addition, such information is used to determine the priorities for research into pest control technology for mung beans. The objectives of the survey reported in this paper were to determine the mung bean pest status and to identify their natural enemies in sampled locations in East Java, Indonesia.

\section{MATERIALS AND METHODS}

\section{Study area}

The locations in East Java sampled for the survey of mung bean pests and their potential natural enemies, conducted in the dry season of 2016, are shown in Figure 1.

\section{Procedures}

The survey began at the end of May and continued until early September 2016. Sampling in the mung bean fields was accomplished using a sweep net $(\varnothing=40 \mathrm{~cm})$. Three locations in each field (village) were swept.The first survey was conducted in Lamongan, Ngawi, Madiun, Nganjuk, and Mojokerto from the end of May until early June 2016. The second survey took place in Madiun at the end of August 2016. The latest survey was conducted in early September 2016 in four districts; Tuban, Ngawi, Madiun and Nganjuk. The districts, sub-districts and villages used as sampling sites are detailed in Table 1. Mung bean pest species and their natural enemies were counted in situ, and crop damage was assessed visually using a simple scoring method. Besides identification by direct observation, mung bean pest species and potential natural enemies of these pests were captured using five single swings of a sweep net in each location (15 single swings for three locations per sample site). Insects captured in the sweep net samples were put into pockets, killed with insecticide, dried in the sun, counted and identified under a stereo microscope (magnification $40 \mathrm{x}$ ), in the laboratory. Identification of insects and natural enemies was achieved by comparison with insect identification key books, preserved specimen samples or illustrated instructions (Boror 1976). If parasitoids emerged from insects, they were collected for

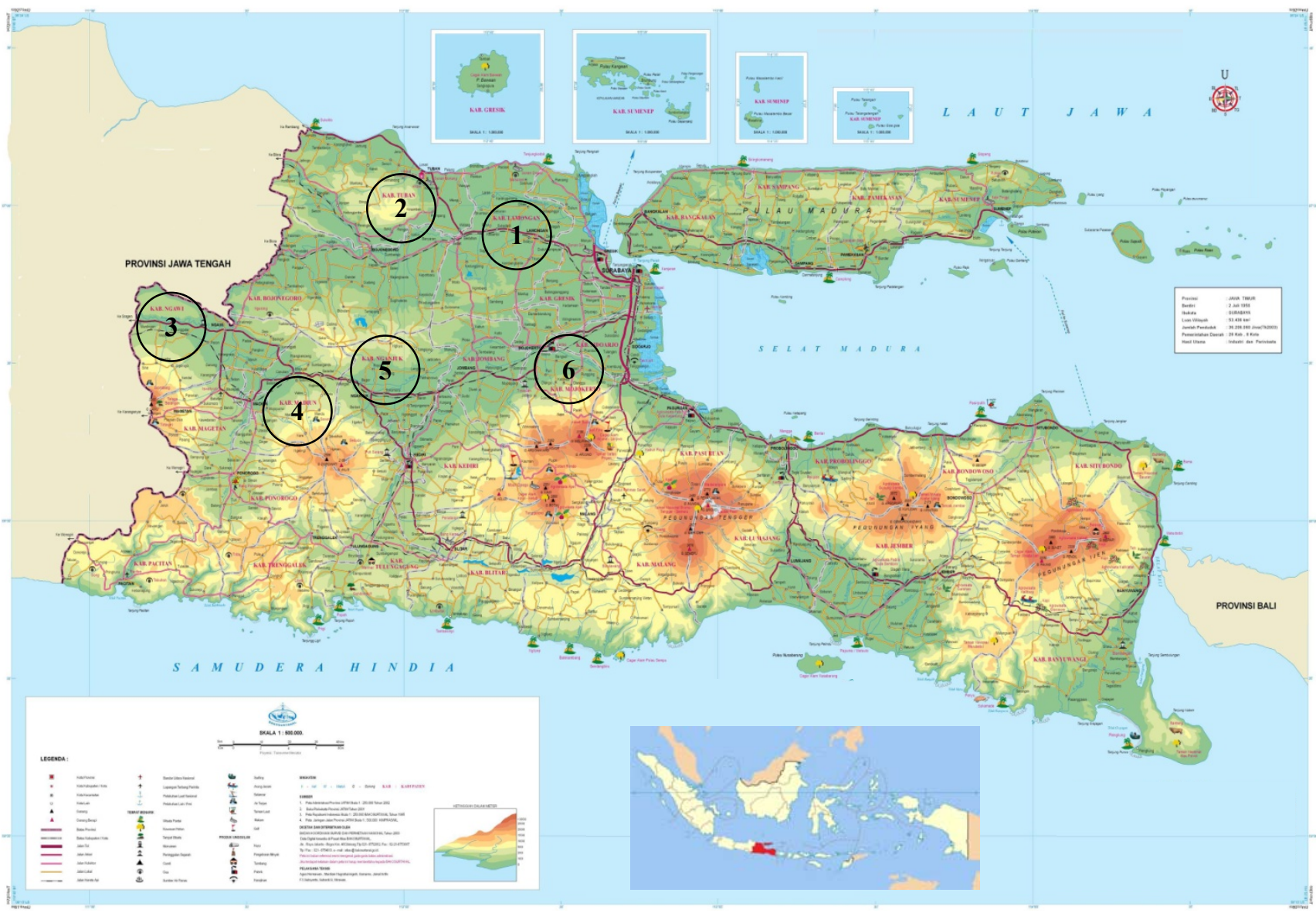

Figure 1. Sampling for the survey of mung bean insect pests and their natural enemies in East Java, Indonesia, was conducted in six areas, i.e. 1. Lamongan, 2. Tuban, 3. Ngawi, 4. Madiun, 5. Nganjuk, 6. Mojokerto 
Table 1. The location of sampling sites in the mung bean pest survey of East Java in 2016

\begin{tabular}{|c|c|c|c|}
\hline District & Sub-district & Village & $\begin{array}{l}\text { Time of } \\
\text { samping }\end{array}$ \\
\hline Lamongan & Brondong & Pungkurlawas & $\begin{array}{l}\text { Late May to } \\
\text { early June }\end{array}$ \\
\hline Tuban & Ranggel & Plumpung & Early September \\
\hline \multirow[t]{2}{*}{ Ngawi } & Paron & Ngale & Early September \\
\hline & Karangjati & Regundi & $\begin{array}{l}\text { Late May to } \\
\text { early June }\end{array}$ \\
\hline \multirow[t]{5}{*}{ Madiun } & Balerejo & Simo & $\begin{array}{l}\text { Late May to } \\
\text { early June }\end{array}$ \\
\hline & Saradan & Sugihwaras & End August \\
\hline & $\begin{array}{l}\text { Mejayan, } \\
\text { Caruban }\end{array}$ & Mejayan & End August \\
\hline & Madiun & Nglames & End August \\
\hline & Pilangkenceng & Muneng & Early September \\
\hline \multirow[t]{4}{*}{ Nganjuk } & Gondong & Balunggebang & Early September \\
\hline & Wilangan & Wilangan & Early September \\
\hline & Bagor & Selorejo & $\begin{array}{l}\text { Late May to } \\
\text { early June }\end{array}$ \\
\hline & Rejoso & Ngangkatan & Early September \\
\hline Mojokerto & Mojosari & Pekukuhan & $\begin{array}{l}\text { Late May to } \\
\text { early June }\end{array}$ \\
\hline
\end{tabular}

identification in the laboratory. The following data were recorded in the field for each survey location: name of county, district, village, host plant species, age of host plants, pest and disease control used by farmers (both insecticides and fungicides were used).

\section{RESULTS AND DISCUSSION}

\section{Lamongan}

In Lamongan, most farmers planted corn and rice. Mung bean was only found in Pungkurlawas village, Brondong. The mung bean was about 50 days old, planted as an intercrop with corn cv. Bisi-2. Both of them were planted at the same time. Farmers in this area generally did not take action to control pests and diseases, so many mung bean plants were found to be infected with leaf spot disease. In this area, we found the bean fly, Ophiomyia phaseoli, thrips, grasshoppers (Atractomorpha crenulata and Xenocatantops sp.), as well as the leaf eating bug Megacopta cribraria (F.) (Table 2). Spiders were the only potential natural pest enemies we observed in this area (Table 3).

Table 2. Species abundance data for insect pests found in mung bean crops in fields sampled in East Java. The survey was conducted in the dry season, 2016.

\begin{tabular}{|c|c|c|c|c|c|c|c|c|c|c|c|c|c|c|c|c|c|}
\hline \multirow[t]{2}{*}{ Sampling location } & \multicolumn{17}{|c|}{ Abundance of pests captured in sweep net* } \\
\hline & RI & Ac & Nv & Pd & Acl & Th & Ud & Em & $\mathbf{K k}$ & Lk & Bll & Co & Cl & Lt & Mr & A.crs & M.cr \\
\hline \multicolumn{18}{|l|}{ Kab. Nganjuk } \\
\hline \multicolumn{18}{|l|}{ Kec. Bagor } \\
\hline Ds. Selorejo & 4 & 11 & 15 & 7 & 21 & 2 & - & - & - & - & - & - & - & - & - & - & - \\
\hline \multicolumn{18}{|l|}{ Kec. Rejoso } \\
\hline Ds. Ngangkatan & - & - & - & 4 & - & 27 & 4 & 34 & 124 & 1 & - & 3 & - & - & - & - & - \\
\hline \multicolumn{18}{|l|}{ Kec. Gondong } \\
\hline Ds. BalongGebang & - & - & - & - & - & 2 & 3 & 29 & - & 1 & 6 & 17 & - & - & - & - & - \\
\hline Ds. Wilangan & - & - & 2 & - & - & 4 & 3 & 107 & - & - & 6 & 13 & - & - & - & - & - \\
\hline \multicolumn{18}{|l|}{ Kab. Madiun } \\
\hline \multicolumn{18}{|l|}{ Kec. Balerejo } \\
\hline Ds. Sinan I & 2 & 1 & - & - & 2 & - & 2 & - & - & 7 & 3 & - & 6 & - & - & - & - \\
\hline Ds. Sinan II & 1 & - & 1 & - & - & 1 & 4 & - & - & 7 & 1 & - & 4 & - & - & - & - \\
\hline \multicolumn{18}{|l|}{ Kec. Pilangkuncung } \\
\hline Ds. Muneng & 1 & - & - & - & - & 3 & - & 40 & 11 & 6 & 6 & 9 & - & - & - & - & - \\
\hline \multicolumn{18}{|l|}{ Kec. Saradan } \\
\hline Ds. Sugihwaras & - & - & - & - & - & - & - & 28 & - & 14 & 6 & - & - & - & - & - & - \\
\hline \multicolumn{18}{|l|}{ Kec. Caruban } \\
\hline Ds. Mejayan & - & - & - & - & - & - & - & 4 & - & 22 & 3 & - & - & - & - & - & - \\
\hline \multicolumn{18}{|l|}{ Kec. Madiun } \\
\hline Ds. Nglames & - & - & - & - & - & - & - & 4 & - & 1 & 5 & - & - & 1 & 1 & - & - \\
\hline \multicolumn{18}{|l|}{ Kab. Mojokerto } \\
\hline \multicolumn{18}{|l|}{ Kec. Mojosari } \\
\hline Ds. Perkukuhan & - & - & 16 & - & - & 3 & 1 & - & - & 16 & - & - & - & - & - & 1 & - \\
\hline \multicolumn{18}{|l|}{ Kab. Lamongan } \\
\hline \multicolumn{18}{|l|}{ Kec. Brondong } \\
\hline Ds. PungkurLawas & - & - & - & - & - & $2-$ & - & - & - & 17 & 3 & 2 & - & - & - & - & 2 \\
\hline \multirow{2}{*}{\multicolumn{18}{|c|}{$\begin{array}{l}\text { Kab. Tuban } \\
\text { Kec. Rangel }\end{array}$}} \\
\hline Kec. Rangel & & & & & & & & & & & & & & & & & \\
\hline Ds. Plumpung & - & - & - & 1 & - & 5 & - & 28 & 8 & 2 & 6 & 3 & - & - & - & - & - \\
\hline \multicolumn{18}{|l|}{ Kab. Ngawi } \\
\hline Kec. Paron & & & & & & & & & & & & & & & & & \\
\hline Ds. Ngale & 1 & - & - & 1 & - & 5 & - & 27 & - & 1 & 6 & 20 & - & - & - & - & - \\
\hline
\end{tabular}

Notes: $\mathrm{Rl}=$ Riptortus linearis, $\mathrm{Ac}=$ Anoplocnemis curvipes, $\mathrm{Nv}=$ Nezara viridula, $\mathrm{Pd}=$ Piezodorus, Acl=Apion clavipes, Th=thrips, $\mathrm{Ud}=$ Spodoptera litura, Em=Empoasca, $\mathrm{KK}=$ whitefly, $\mathrm{Lk}=$ bean fly, $\mathrm{Bll}=$ Grasshopper, $\mathrm{Cl}=$ Cletus $s p, \mathrm{Lt}=$ Longitarsus, $\mathrm{Mr}=$ Maruca virata, A.crs =Apoderus crenatus, M.cr =Megacopta cribraria, Co =Coleoptera. $*$ Number of each species per 15 single swings of the insect net; - = no insect found. Kab. = district, Kec. = subdistrict, Ds. = village 
Table 3. Abundance of natural enemies of insect pests on mung bean crops in East Java. Dry season 2016

\begin{tabular}{|c|c|c|c|c|c|c|c|c|c|c|c|c|c|c|c|}
\hline \multirow{2}{*}{ Sampling location } & \multicolumn{15}{|c|}{ Species and population numbers of natural enemies* } \\
\hline & Rv & H Pd & Lb & Tg & $\mathrm{Br}$ & Sy & Hm & Ich & Co & Te & H Pr & Lb K & LHP & $\mathbf{C p}$ & $\mathbf{P a}$ \\
\hline \multicolumn{16}{|l|}{ Kab. Nganjuk } \\
\hline \multicolumn{16}{|l|}{ Kec. Bagor } \\
\hline Ds. Selorejo & 1 & 1 & - & - & - & - & - & - & 1 & - & - & - & - & - & - \\
\hline \multicolumn{16}{|l|}{ Kec. Rejoso } \\
\hline Ds. Ngangkatan & - & - & 7 & 8 & 2 & - & - & - & - & - & - & - & - & - & - \\
\hline \multicolumn{16}{|l|}{ Kec. Gondong } \\
\hline Ds. BalongGebang & - & - & 9 & 7 & 14 & 1 & - & - & - & - & - & - & - & - & - \\
\hline \multicolumn{16}{|l|}{ Kec. Wilangan } \\
\hline Ds. Wilangan & - & - & 14 & - & 4 & - & - & 1 & 2 & - & - & - & - & - & - \\
\hline \multicolumn{16}{|l|}{ Kab. Madiun } \\
\hline \multicolumn{16}{|l|}{ Kec. Balerejo } \\
\hline Ds. Sinan I & - & - & 4 & - & - & - & 1 & - & 1 & - & - & - & - & - & - \\
\hline Ds. Sinan II & - & - & 2 & - & 1 & - & 1 & - & - & - & - & - & - & - & - \\
\hline \multicolumn{16}{|l|}{ Kec. Pilangkuncung } \\
\hline Ds. Muneng & - & - & 15 & - & 4 & - & - & - & - & - & - & - & - & - & - \\
\hline \multicolumn{16}{|l|}{ Kec. Saradan } \\
\hline Ds. Sugihwaras & - & - & 18 & - & - & - & 59 & - & 2 & 4 & - & - & - & - & - \\
\hline \multicolumn{16}{|l|}{ Kec. Caruban } \\
\hline Ds. Mejayan & - & - & 6 & - & - & - & 52 & - & 1 & - & - & - & - & - & - \\
\hline \multicolumn{16}{|l|}{ Kec. Madiun } \\
\hline Ds. Nglames & - & - & 5 & - & - & - & 17 & - & 3 & 1 & - & - & - & - & - \\
\hline \multicolumn{16}{|l|}{ Kab. Mojokerto } \\
\hline \multicolumn{16}{|l|}{ Kec. Mojosari } \\
\hline Ds. Perkukuhan & - & - & - & - & - & - & - & - & 1 & - & 1 & 1 & - & - & - \\
\hline \multicolumn{16}{|l|}{ Kab. Lamongan } \\
\hline \multicolumn{16}{|l|}{ Kec. Brondong } \\
\hline Ds. PungkurLawas & - & - & 1 & - & - & - & - & - & - & - & - & - & 1 & - & - \\
\hline \multicolumn{16}{|l|}{ Kab. Tuban } \\
\hline \multicolumn{16}{|l|}{ Kec. Rangel } \\
\hline Ds. Plumpung & - & - & 7 & - & 2 & - & - & - & 3 & 1 & - & - & - & - & - \\
\hline \multicolumn{16}{|l|}{ Kab. Ngawi } \\
\hline \multicolumn{16}{|l|}{ Kec. Paron } \\
\hline Ds. Ngale & - & - & 6 & - & 3 & - & - & - & 3 & - & - & - & - & 1 & - \\
\hline
\end{tabular}

Notes: $\mathrm{Rv}=$ Reduviidae, $\mathrm{H}$ Pd =Hymenoptera Predator, $\mathrm{Lb}=$ spiders, $\mathrm{Tg}=$ Trichogrammatidae, $\mathrm{Br}=\mathrm{Braconidae}, \mathrm{LHP}=$ spider black white, $\mathrm{Sy}=$ Syrphidae, $\mathrm{Hm}=$ Heminoptera, $\mathrm{Ich}=$ Ichneumonidae, $\mathrm{Co}=$ Coccinellidae, $\mathrm{Tc}=$ Tachinidae, $\mathrm{H} \mathrm{Pr}=$ Heminoptera $\mathrm{Parasite}, \mathrm{Lb}$ $\mathrm{K}=$ spider yellow, $\mathrm{Cp}=$ dragon flies, $\mathrm{Pa}=$ Paederus; ${ }^{*}$ Number of each species type per 15 single swings of the insect net; - = no species type found. Kab. $=$ district, Kec. $=$ subdistrict, Ds. $=$ village

\section{Tuban}

In Tuban, the survey was conducted in early September. Mung bean crops were only found in the village of Plumpung, in sub-district Ranggel. At that time, the mung bean plants were in the vegetative phase and were planted as a monoculture. Mung beans grew well, so that farmers did not need to conduct pest control measures. In the area around the sampling location, most farmers planted corn. The pests that we found were Homoptera (Empoasca spp.), thrips, Hemiptera (Piezodorus spp.), grasshoppers ( $A$. crenulata), and whitefly (Bemisia tabaci) (Table 2). Natural enemies that we found in this area were spiders, coccinellid beetles and parasitoids of the families Tachinidae and Braconidae (Table 3).

\section{Ngawi}

In Ngawi, sampling in the mung bean fields was carried out in early September. At this time, most farmers had planted corn and legumes. In general, pest control was rarely carried out by farmers in their mung bean fields. Observation of mung bean pests was conducted in the Experimental Garden of Ngale, Paron. Pest control is regularly carried out at this institution. The pests we found were grasshoppers (A. crenulata), Hemiptera (Piezodorus hybneri; Riptortus linearis), Homoptera (Empoasca spp.), and thrips (order Thysanoptera) (Table 2). The natural enemies we found at this location were spiders, a dragonfly, coccinellid beetles, and Braconidae (Table 3).

\section{Madiun}

Observations of mung bean pests were conducted three times in Madiun. In early June, farmers were still planting rice. In the village of Simo, Balerejo sub-district, the farmers planted mung beans in monoculture. At that time, the plants were 40 days old. Farmers planted mung bean for seed for the next planting season (July). In this area we found grasshoppers, pod sucking bugs (Nezara viridula, $P$. hybneri, $R$. linearis, Cletus sp. ), leaf-eating caterpillars 
(Spodoptera litura), bean fly, and thrips, all in low numbers (Table 2). We also discovered a new pest of mung beans: Apion clavipes Gerst. (Curculionidae). The second survey in Maduin district was conducted in late August 2016; samples were taken in three sub-districts Saradan, Caruban, and Madiun. In each sub-district, the mung bean crops sampled were between 30-days old and harvest. In this area we found grasshoppers, bean fly, and Homoptera (Empoasca spp), all in low numbers (Table 2). The third survey was conducted at the beginning of September 2016 , with sampling conducted in Village Muneng, Sub-district Pilangkenceng. Most farmers in this area were planting rice, soybeans and mung beans at the time of the survey. Mung bean plants in the survey areas were 45 days old. Insect pests found during this third survey were grasshoppers (A. crenulata), whitefly (B. tabaci), Coleoptera (Longitarsus sp.), Hemiptera (M. testulalis, $R$. linearis, Empoasca spp.), and thrips (Table 2). Natural enemies found based on all three survey visits in Madiun were spiders, Tachinidae, Braconidae, Hymenoptera, and coccinellid beetles (Table 3). In general, pest control was rarely carried out by farmers in these mung bean fields.

\section{Nganjuk}

Survey visits were carried out twice in four sub-districts Gondang, Bagor, Wilangan and Rejoso. In early June, most farmers were still planting rice in their fields. In June, sampling was carried out at Selorejo, Sub-district Bagor. In this village, we found one farmer's field had mung bean as a monoculture. Plants had reached the pod production stage, but the crop was not in good condition, having many pests and diseases (Figure 2). The population of pod sucking bugs and pod borers was relatively high, with many flowers falling, which was an indicator of thrip attack in the flowering phase. As a result, the extent of pod production was poor, and most pods were holey. Insects caught in the sweep net were $N$. viridula, P. hybneri, $R$. linearis, Cletus sp., Anoplocnemes curvipes (F.), thrips and A. clavipes (Curculionidae), in high number (Table 2). The pod borer weevil, A. clavipes (Curculionidae) is a new mung bean insect pest in this area and was found in high number, so that many mung bean pods were severely damaged. In the second survey, in early September 2016, samples were taken at three villages, Balunggebang, Ngangkatan and Wilangan. Around these sample locations, farmers' fields were mostly planted with rice in a cropping pattern of rice, soybeans and mung beans. Pests species found were leaf-eating caterpillars S. litura, whiteflies $B$. tabaci, Empoasca sp., P. hybneri, bean fly, thrips, leafeating beetles, grasshoppers $A$. crenulata, and pod-sucking bugs $N$. viridula (Table 2). Natural enemies found in Nganjuk were spiders, Tachinidae, Braconidae, Trichogrammatidae and Syrphidae (Table 3). Pest control of mung bean is rarely carried out in these mung bean fields.

\section{Mojokerto}

Observation of mung bean pests was conducted in the Mojosari Research Station (Pekukuhan village), in early June. Mung bean variety Vima-3 was planted in monoculture, and the plants were 35 days old. Pest control was done periodically at this institution. At this site, we found pod sucking bugs ( $N$. viridula, $R$. linearis), leafeating caterpillars ( $S$. litura), bean fly, thrips and leaf beetles Apoderus crenatus (Voss) (Table 2). Natural enemies of pests found were a spider, Paederus fuscipes (Curtis), and Coccinella (L.) beetles (Table 3)

\section{Discussion}

In general, a major pest of mung bean was found in each district surveyed (Table 2). The species composition of the main pest populations differed in each district. Differences in species composition can be attributed to differences in the distribution of host plants, the growth stage of host plants, pest control and cropping patterns in the area (Evans et al. 2013). Matsubayashi et al. (2011) consider that the specificity of a host as a feed source is one of the most important factors explaining insect diversity. Most pests have several species of host plants in one Family as a potential food source, but less than $10 \%$ of pest species have more than three plant Families as their potential hosts (Schoonhoven et al. 2005).

The pests species present in the mung bean fields in East Java were found to be: pod sucking bugs ( $N$. viridula, $P$. hybneri, $R$. linearis), thrips, armyworms, whitefly, leafhoppers (Empoasca sp.), beans fly, bean pod borer ( $M$. virata), leaf-beetles and grasshoppers (A. crenulata). Among these pests, pod sucking bugs were the most important pests in all mung bean field areas. Pod sucking bugs are an important pest and are polyphagous insects (Figure 3). These pests attack several species in the family Leguminosae, such as soybeans, mung beans, peanuts, pigeon pea, cowpea, common beans, alfalfa, Crotalaria sp., and Sesbania rostrata (Funayama 2006; Nakamura and Numata 2006). Pod sucking bugs are widespread in tropical and sub-tropical areas, including Indonesia, South Japan, America, Australia, and Europe (Musser et al. 2010; Temple et al. 2011; Wada et al. 2006). Pod sucking bugs cause economic damage as a result of a decreased ability for seeds to grow; a decrease in grain quality and yield; a decline in seed vigor because of tissue damage due to puncture of the seed; as well as a delay in the maturing of the plant (Leonard et al. 2011). According to Arifin and Tengkano (2010), nymph and adult stages of $P$. hybneri attack the plants at 42 days after planting (DAP), but the symptoms of the damage are observed at 63 DAP. Based on our observation of species composition, status, and regional spread of pests, mung bean cultivation in East Java appears seriously threatened, especially by pod sucking bugs, $N$. viridula, $P$. hybneri and $R$. linearis, such that insect population reduction or other preventative action needs to be carried out.

Another important outcome of this survey was the discovery, in the village of Pungkurlawas, Brondong, Lamongan, of a new mung bean pest species, Megacopta cribraria (F). Kudzu bug, M. cribraria (Hemiptera: Heteroptera: Plataspidae), is an insect native to Asia and Australia, previously known as the bean plataspid, lablab bug or globular stink bug (Eger et al. 2010). In October 2009, a large population of kudzu bug was found in the 
walls of houses near the leguminous species kudzu, Pueraria montana Lour. (Merr.), in nine counties in northeast Georgia, USA. In August 2010, the insect was found in 48 counties in northeast Georgia and 13 counties in northwest South Carolina (Eger et al. 2010). Two years latter, M. cribraria populations had spread to most of Georgia, South Carolina and North Carolina (Zhang et al. 2012), with additional sightings in Virginia and Alabama (Gardner et al. 2013; Reisig and Bacheler 2013). Currently, kudzu bug populations have spread to all districts of South Carolina; most counties in Georgia and North Carolina; to Alabama, and most districts that grow soybeans in Virginia, Florida, Tennessee and Mississippi and in parts of Arkansas and Louisiana; and continue to spread every year (Gardner 2015). In Malang (East Java, Indonesia), this insect was found for the first time on soybean plants in 2013. Now, in 2016, this bug is reorded here as a new pest of mung beans, in Lamongan.

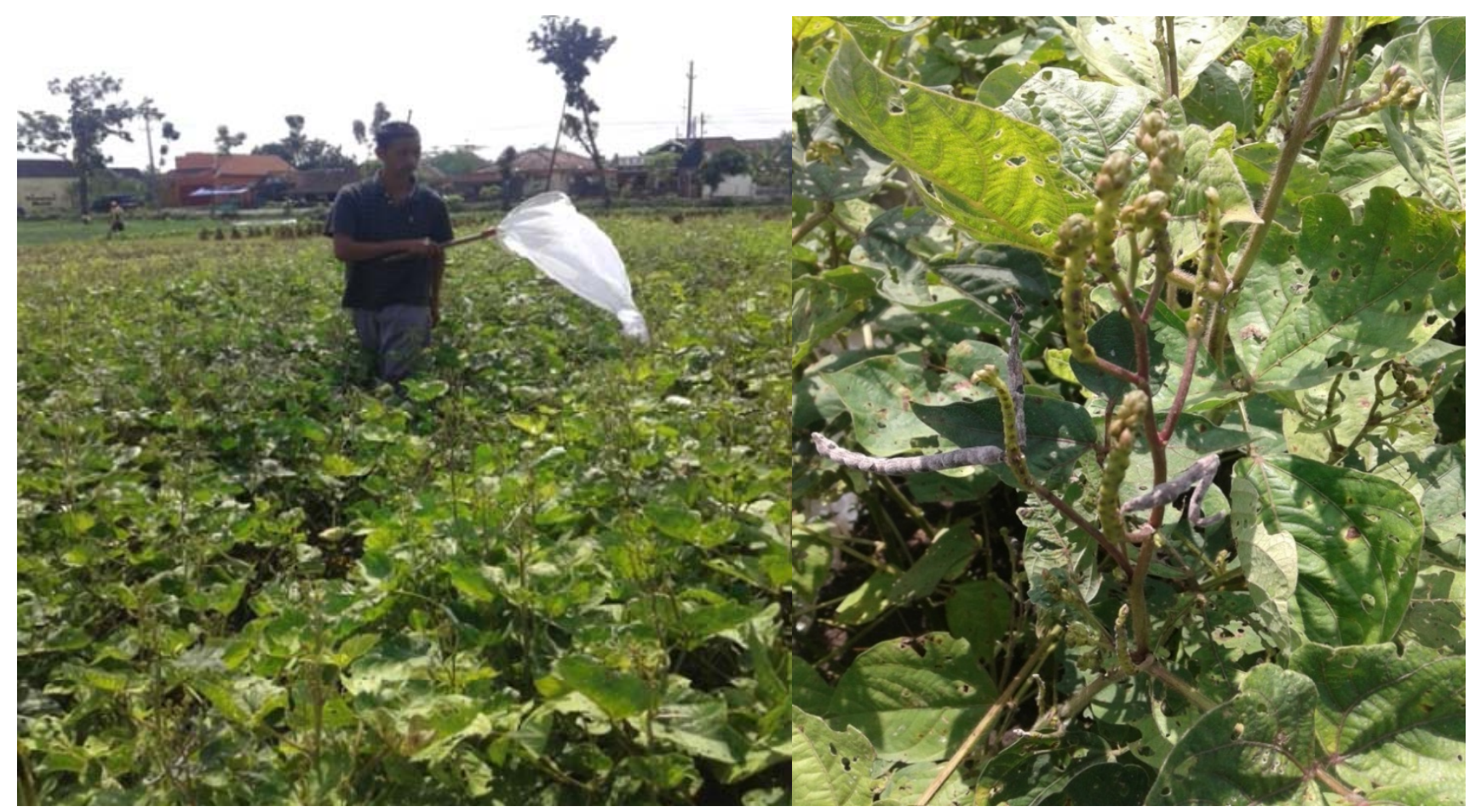

Figure 2. Insect samples were taken using a sweep net in a mung bean farmer's field at Nganjuk (left); mung bean crop damage by a complex of pests - including thrips, pod-sucking bugs, and pod-borers - as well as by plant diseases (right).

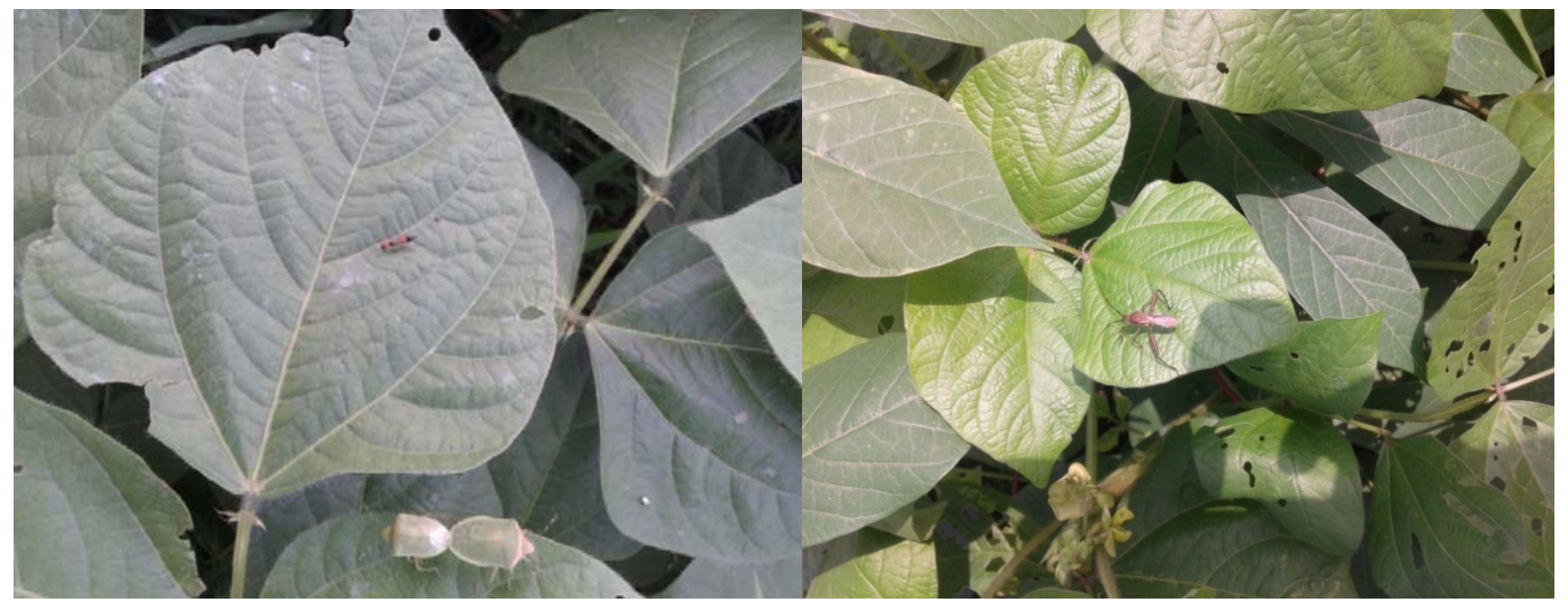

Figure 3. Pod sucking bugs (Nezara viridula and Riptortus linearis) are dominant pests on mung bean, and predator Paederus fuscipes were found in East Java 
Kudzu bugs have a piercing-sucking mouth type. They are suspected of eating the phloem, reducing soybean yields by sucking stem, leaf petioles and leaves (Suiter et al. 2010; Thippeswamy and Rajagopal 2005), and by diverting nutrients and moisture away from plants' vegetative and reproductive growth (Waldvogel and Alder 2011). Kudzu bugs are commonly found forming aggregates on the main stem of soybean (Del PozoValdivia 2016; Suiter et al. 2014). On soybean crops, kudzu bugs cause a significant reduction in crop yields (Blount et al. 2016; Del Pozo-Valdivia et al. 2016; Seiter et al. 2013). Studies in Southern and Central China show that severe pest attacks cause defoliation and disorders of photosynthesis as a result of sooty mold which grows on the excretion of M. cribraria (Zhang et al. 2012). Soybean yield losses due to damage from kudzu bug have been reported in the range of $1-50 \%$ (Eger et al. 2010). In addition, this pest has the potential to cause direct damage to the skin and eyes of humans from their defensive chemicals (Ruberson et al. 2013).

Another new finding from this survey was the recording of the pod borer weevil, Apion clavipes Gerst. (Curculionidea), in Madiun and Nganjuk. The population of this pest was so high that it resulted in damage to the mung bean pods. Occurrence of new pests should be anticipated and monitored at all times, in order to forestall economic damage to crops. Besides its occurrnce as a new pest on mungbean, this weevil has also been recorded on other host plant species i.e. blackgram, redgram, soybean and cashew (Umesha 2006). In India, A. amplum (Faust) (Apionidae: Coleoptera) is an important pest in mung beans and blackgram, and it may cause damage pods up to $49 \%$ (Deshmukh et al. 2007). In India, this insect is a major podborer pest of pigeon pea, and has caused high yield losses (Azad Thakur and Firake 2013; Dialoke et al. 2014; Sandip Patra et al. 2016)

Survey of pests and natural enemies in specific agroecosystems should be done periodically so that the fluctuations in pest populations, changes in pest status and pest dominance, and emergence of new primary pests can be identified quickly and accurately, and appropriate action taken.

\section{ACKNOWLEDGEMENTS}

My thanks go to Dandy SB, Hari Atim and Suntono, who helped implement the research; which was funded by the Indonesian Agency for Agricultural Research and Development (IAARD), Jakarta.

\section{REFERENCES}

Arifin M, Tengkano W. 2010. The economic damage level of legume shield bug, Piezodorus hybneri on soybeans. Journal of Food Crops Research 29 (1): 42-49.

Azad Thakur NS, Firake DM. 2013. Insect pest of pulses in North Eastern Himalaya and rationale for their management. http://www.krishisewa.com/articles/disease-management/219-pulsesinsect-pests.html. Accessed on 1 September 2016.
Baliadi Y. 2007. Natural enemies, host plants, and Aphis glycines control with botanical pesticides in dry land of Lampung Province. In: Harnowo D, Rahmania AA, Suharsono (eds) Increased Production of Pulses and Tubers Supporting Food Self-Reliance. Puslitbangtan, Jakarta.

Basuki I, Hastuti S, Hipi A, Kukuh WW. 2011. Profit level of mung bean farming system as a superior commodity in NTB. http:// ntb.litbang.deptan.go.id. Accessed on 10 August 2011.

Blount JL, Buntin GD, Roberts PM. 2016. Effect of planting date and maturity group on soybean yield response to injury by the kudzu bug, Megacopta cribraria F. (Hemiptera: Plataspidae) J Econ Entomol 109: 207-212.

Borror DJ, and Delong DM. 1976. An Introduction to Study of The Insect. 4th edition. Holt, Rinehart and Winston, New York.

BPS. 2012. Publication of Food Crop Production Forecast II 2012. Badan Pusat Statistik. Jakarta.

Del Pozo-Valdivia AI, Seiter NJ, Reisig DD, Greene JK, Reay-Jones FPP, Bacheler JS. 2016. Megacopta cribraria (Hemiptera: Plataspidae) population dynamics in soybeans as influenced by planting date, maturity group, and insecticide use. J. Econ. Entomol. 109:11411155.

Del Pozo-Valdivia AI. 2016. Effects of Agronomic Practices on the Invasive Soybean Pest Megacopta cribraria (Hemiptera: Plataspidae) [Dissertation]. North Carolina State University. Raleigh, NC, USA.

Deshmukh SS, Goud KB, Giraddi RS. 2007. Seasonal incidence and crop loss estimation of pod weevil, Apion amplum (Faust) on greengram, Vigna radiata (L.) Wilczek. Karnataka J Agric Sci 20 (4): 855-856.

Dialoke SA, Emosairue SO, EGho EO, Ogoke IJ. 2014. Insect species associated with early maturing pigeon pea in Nigeria. Indian $\mathrm{J}$ Entomol 76(4): 330-336.

Director General of Food Crops. 2012. Roadmap for Peanut and Mung bean Production Year 2010-2014. Directorate General of Food Crops, Jakarta.

Eger JE Jr, Ames LM, Suiter DR, Jenkins TM, Rider DA, Halbert SE. 2010. Occurrence of the Old World bug Megacopta cribraria (Fabricius) (Heteroptera: Plataspidae) in Georgia: A serious home invader and potential legume pest. Insecta Mundi, 121:1-11.

Evans LM, Allan GJ, Meneses N, Max TL, Whitham TG. 2013. Herbivore host-associated genetic differentiation depends on the scale of plant genetic variation examined. Evol Ecol 27: 65-81.

Funayama K. 2006. A new rearing method using carrots as food for the brown marmorated stink bug, Halyomorpha halys (Stal) (Heteroptera: Pentatomidae). Appl. Entomol. Zool. 41 (3): 415-418.

Gardner W. 2015. Megacopta cribraria Distribution Map. [accessed on 20 November 2015]. Available online: http://www.kudzubug.org/distribution-map/

Gardner WA, Peeler HB, LaForest J, Roberts PR, Sparks AN, Jr Greene JK, Reisig DD, Suiter DR, Bacheler JS, Kidd K. 2013. Confirmed distribution and occurrence of Megacopta cribraria (F.) (Hemiptera: Plataspidae) in the Southeastern United States. J Entomol Sci 48: 118127.

Indiati SW. 2015. Thrips pest management through integrated pest management approach. J Agric Res 34 (2): 51-60.

Kogan M, Turnipseed SG. 1987. Ecology and management of soybean arthropods. Ann Rev Entomol 32: 507-538.

Leonard BR, Boquet DJ, Padgett B, Davis JA, Schneider R, Griffin JL, Valverde RA, Levy RJJr. 2011. Soybean green plant malady contributing factors and mitigation. Louisiana Agric 54: 32-34.

Marwoto, Suharsono. 2008. Strategy and control of armyworm (Spodoptera litura Fabricius) on soybean. Journal of Agricultural Research 27 (4): 131-136.

Matsubayashi KW, Kahono S, Katakura, H. 2011. Divergent host plant specialization as the critical driving force in speciation between populations of a phytophagous ladybird beetle. J Evol Biol 24: 14211432.

Musser FR, Lorenz GM, Stewart SD, Catchot AL. 2010. Soybean insect losses for Mississippi, Tennessee, and Arkansas. Midsouth Entomol 4: $22-28$.

Nakamura K, Numata H. 2006. Effects of photoperiod and temperature on the induction of adult diapause in Dolycoris baccarum (L.) (Heteroptera: Pentatomidae) from Osaka and Hokkaido, Japan. Appl Entomol Zool 41 (1): 105-109.

Radjit BS, Prasetyawati N. 2012. Prospects mung beans dry season in Central Java. Bulletin Palawija 24: 57-68. 
Reisig, D, Bacheler J. 2013. Kudzu bug (Megacopta cribraria), a new potentially devastating pest of soybeans. North Carolina State University Extension Entomology, Raleigh, NC, USA.

Ruberson JR, Takatsu K, Buntin GD, Eger JE, Jr Gardner WA, Greene JK, Jenkins TM, Jones WA, Olson DM, Roberts PM. 2013. From Asian curiosity to eruptive American pest: Megacopta cribraria (Hemiptera: Plataspidae) and prospects for its biological control. Appl Entomol Zool 48:3-13.

Sandip Patra, Firake DM, Azad Thakur NS, Roy A. 2016. Insect pes complex and crop losses in pigeon pea in medium altitude hill of Meghalaya. The Bioscan 11(1): 297-300.

Schoonhoven LM, van Loon JJA, Dicke M. 2005. Insect-Plant Biology, 2nd ed. University Press, Cambridge.

Seiter NJ, Greene JK, Reay-Jones FP. 2013. Reduction of soybean yield components by Megacopta cribraria (Hemiptera: Plataspidae) J Econ Entomol 106:1676-1683.

Seiter NJ, Greene JK, Reay-Jones FPF. 2014. Aggregation and oviposition preferences of Megacopta cribraria (Hemiptera: Plataspidae) in laboratory bioassays. J Entomol Sci 49:331-335.

Suiter DR, Eger JE, Jr Gardner WA, Kemerait RC, All JN, Roberts PM, Greene JK, Ames LM, Buntin GD, Jenkins TM. 2010. Discovery and distribution of Megacopta cribraria (Hemiptera: Heteroptera: Plataspidae) in northeast Georgia. J Integr Pest Manag 1:1-4.

Temple J, Davis JA, Hardke J, Price P, Micinski S, Cookson C, Richter A, and Leonard BR. 2011. Seasonal abundance and occurrence of the redbanded stink bug in Louisiana soybeans. Louisiana Agric 54: 2022 .

Tengkano W. 1986. Identification and bioecology of insect pest of soybean and mungbean. Training Course on Integratrd Pest Management of Legumes and Coarse Grains. FAO Biotrop. Bogor, July 15 Agust, 1986.

Thippeswamy C, Rajagopal BK. 2005. Life history of lablab bug, Coptosoma cribraria Fabricius (Heteroptera: Plataspidae) on field bean, Lablab purpoureus var. lignosusmedikus. Karnataka J Agric Sci 18: $39-43$

Umesha AJ. 2006. Studies on seasonal incidence and management of Apion amplum (Faust) (Apinonidae: Coleoptera) on greengram. [Thesis]. University of Agricultural Sciences, Dharwad.

Wada T, Endo N, Takahashi M. 2006. Reducing seed damage by soybean bugs by growing small-seeded soybeans and delaying the sowing time. Crop Protect 25: 726-731.

Waldvogel M, Alder P. 2011. Kudzu Bug-A Nuisance and Agricultural Pest. Residential, Structural and Community Pests-ENT/rsc\#37.. North Carolina State University Department of Entomology Insect Notes. Raleigh, NC, USA.

Zhang Y, Hanula JL, Horn S. 2012. The biology and preliminary host range of Megacopta cribraria (Heteroptera: Plataspidae) and its impact on kudzu growth. Environ Entomol 41: 40-50. 